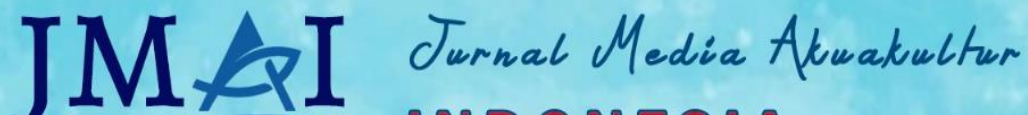 D N D O N ESAA
}

https://journal.unram.ac.id/index.php/jmai/index. E-ISSN : 2798-0553

VOLUME 1, NOMOR 1, JUNI 2021

\section{KAJIAN KERENTANAN PESISIR UNTUK BUDIDAYA LAUT DI PULAU DULLAH, KOTA TUAL}

\author{
Henny Fitrinawati \\ Program Studi Budidaya Perikanan, Politeknik Perikanan Negeri Tual \\ Jalan Raya Langgur Sathean km 6, Maluku Tenggara, Provinsi Maluku \\ Alamat korespondensi : henny.fitrinawati@polikant.ac.id
}

\begin{abstract}
ABSTRAK
Perikanan budidaya menyediakan lebih dari setengah dari pasokan makanan laut di dunia dengan pasokan ikan per kapita dunia mencapai rekor pada tahun 2014 yaitu $20 \mathrm{~kg}$. Indonesia memiliki potensi perikanan budidaya terbesar di dunia yakni 67,7 juta ton per tahun. Jika ditinjau dari ketersediaan air tawar yang semakin berkurang, sebagaian besar pertumbuhan perikanan budidaya akan berlangsung dalam air laut. Peneltian ini bertujuan untuk menganalisis tingkat kerentanan di wilayah pesisir Pulau Dullah, Kota Tual melalui pendekatan spasial. Penelitian dilakukan di Teluk Luv (Pulau Dullah bagian selatan) dan Teluk Divur (Pulau Dullah bagian utara) yang merupakan bagian dari Kecamatan Dullah Utara.Penentuan kerentanan pesisir teluk dilakukan untuk mengetahui nilai indeks kerentanan pesisir teluk menggunakan modifikasi konsep kerentanan pesisir Gornitz dan White(1992). Metode penelitian kerentanan pesisir teluk menggunakan pendekatan spasial dengan berdasarkan pada kondisi fisik pesisir telukyaitu geomorfologi, perubahan garis pantai, elevasi, kenaikan muka laut relatif, tunggang pasang maksimal dan tinggi gelombang. Indeks kerentanan pesisir teluk dibagi ke dalam tigakelas yaitu rendah, sedang dan tinggi. Penilaian secara kuantitatif terhadap kerentanan pesisir dilakukan melalui scoring. Luaran penelitian ini adalah berupa peta kerentanan wilayah pesisir Pulau Dullah. Teluk Divur dan Teluk Luv memiliki perairan yang masuk kedalam kategori tidak rentan hingga rentan sedang dengan nilai indeks kerentanan berkisar 0,00-19,37. Posisi mulut teluk memiliki tingkat kerentanan yang lebih tinggi dari teluk bagian dalam.
\end{abstract}

Kata Kunci budidaya laut, kerentanan, pesisir, Pulau Dullah

Tracebility Tanggal diterima : 20 Mei 2021. Tanggal publikasi : 23 Juni 2021

Panduan Fitrinawati, H. (2021). Kajian Kerentanan Pesisir Untuk Budidaya Laut di

Kutipan

(APPA $7^{\text {th }}$ )
Pulau Dullah, Kota Tual. Jurnal Media Akuakultur Indonesia, 1 (1), 49-

57. http://doi.org/10.29303/mediaakuakultur.v1i1.118 


\section{PENDAHULUAN}

Keberadaan pulau-pulau kecil sangat penting bagi pembangunan nasional, bukan saja karena jumlahnya yang banyak, melainkan juga karena memiliki kawasan pesisir dan laut yang mengandung sumberdaya alam dan jasa lingkungan yang sangat kaya. Kekayaan sumberdaya alam tersebut menimbulkan daya tarik bagi berbagai pihak untuk memanfaatkannya dan berbagai instansi untuk meregulasinya.Potensi budidaya laut ini juga harus didukung dengan kondisi ekosistem laut yang baik terutama jika dilakukan di pulau-pulau kecil. Pulau kecil memiliki kerentanan yang lebih besar terhadap perubahan iklim daripada mainland karena pulau kecil menjadi yang pertama merasakan efek buruk dari perubahan iklim.

Saat ini perikanan budidaya menyediakan lebih dari setengah dari pasokan makanan laut di dunia dengan pasokan ikan per kapita dunia mencapai rekor pada tahun 2014 yaitu $20 \mathrm{~kg}$ (FAO 2016). Indonesia memiliki potensi perikanan budidaya terbesar di dunia yakni 67,7 juta ton per tahun yang berasal dari budidaya laut 47 juta ton per tahun, budidaya perairan payau (tambak) 15 juta ton per tahun dan budidaya perairan tawar 5,7 juta ton. Pada tahun 2015 total produksi perikanan budidaya baru sebesar 10,074 juta ton atau 14,88 \% dari total potensi produk lestarinya (Pusdatin KKP 2015). Jika ditinjau dari ketersediaan air tawar yang semakin berkurang, sebagaian besar pertumbuhan perikanan budidaya akan berlangsung dalam air laut. Budidaya laut merupakan bagian dari budidaya perikanan yang didefinisikan sebagai intervensi yang terencana dan sengaja oleh manusia dalam proses produksi organisme akuatik seperti ikan (finfish), udang (krustasea), moluska, ekinodermata, dan alga (Effendi 2004). Luas perairan dangkal nasional yang cocok untuk budidaya laut (rumput laut, ikan kerapu, kakap, baronang, kerang) sekitar 24,5 juta ha (Kep Men Kelautan dan Perikanan No.18/2011). Jika ditaksir kasar berdasarkan nilai yang dihitung Costanza et al. 1997 maka dapat diperkirakan potensi nilai ekonomi ekosistem perairan tersebut (as coastal shelf) adalah US\$ 53,3 milyar per tahun/ Rp. 37,31 trilyun. Nilai ekonomi ekosistem perairan laut nasional yang telah digambarkan jika dikelola dengan falsafah pendekatan ekosistem yang terintegrasi dari darat ke laut merupakan peluang kekuatan ekonomi yang besar bagi pembangunan kesejahteraan Indonesia pada umumnya dan pemerintah daerah pada khususnya.

Potensi budidaya laut ini juga harus didukung dengan kondisi ekosistem laut yang baik terutama jika dilakukan di pulau-pulau kecil. Pulau kecil memiliki kerentanan yang lebih besar terhadap perubahan iklim daripada mainland karena pulau kecil menjadi yang pertama merasakan efek buruk dari perubahan iklim (Tompkins et al. 2005). Kerentanan juga terjadi pada aktivitas budidaya laut di pulau kecil walaupun perubahan iklim hanya salah satu ancaman di luar faktor lingkungan dan faktor aktivitas manusia tetapi dapat mempersulit untuk mencapai pengelolaan budidaya yang berkelanjutan (FAO 2008).

Pulau Dullah merupakan pulau terbesar dari 66 pulau yang termasuk kedalam Kota Tual dan memiliki panjang garis pantai 85,85 km serta luas wilayah sebesar 93,32 $\mathrm{km}^{2}$. Kondisi wilayah terutama pesisir dan laut yang ada di Pulau Dullah sangat mendukung untuk dikembangkannya perikanan budidaya khususnya budidaya laut. 
Potensi luas lahan budidaya laut di wilayah Kota Tual mencapai 7.524 ha yang meliputi lahan budidaya mutiara 924 ha, lahan budidaya teripang 3.100 ha, lahan budidaya lola 1.000 ha, lahan budidaya rumput laut 2.500 ha dan selebihnya dapat digunakan untuk budidaya ikan (Dinas Kelautan dan Perikanan Kota Tual 2010). Komoditas yang telah dibudidayakan oleh masyarakat Kota Tual diantaranya adalah rumput laut, ikan kerapu, dan tiram mutiara. Produksi budidaya laut di Kota Tual pada tahun 2013 sebesar 145.578 ton (BPS Maluku Tenggara 2013). Kawasan perairan Pulau Dullah yang menjadi lokasi budidaya laut diantaranya adalah Teluk Luv dan Teluk Divur namun pemanfaatannya belum optimal dikarenakan kendala modal, kualitas pembudidaya yang relatif rendah, serta sarana dan prasarana yang belum memadai sehingga lambat dalam menyerap teknologi. Budidaya laut yang telah dilakukan ini diduga tanpa memperhitungkan aspek daya dukung lingkungan karena masih tradisional yang apabila tetap berlanjut kemungkinan akan terjadi penurunan kualitas perairan sehingga berdampak pada turunnya kualitas dan produktivitas komoditas budidaya laut serta pendapatan nelayan.

Budidaya laut yang telah dikembangkan masyarakat Pulau Dullah saat ini belum mencapai hasil yang maksimal dengan salah satu indikasi tingkat ekonomi pembudidaya laut yang belum merata dan dikhawatirkan akan mengurangi produktivitas serta dapat menghambat keberlanjutan budidaya laut. Beberapa penyebabnya diantaranya adalah belum adanya analisis kelayakan budidaya laut yang telah dilakukan seperti kelayakan lokasi dan kelayakan usaha. Masyarakat melakukan budidaya laut hanya berdasarkan pada pengamatan visual terhadap lokasi yang dianggap layak oleh pembudidaya dan perhitungan ekonomis yang sederhana. Lokasi budidaya laut yang ada juga belum memperhatikan faktor kerentanan lingkungan perairan tersebut terhadap perubahan musim. Selain kelayakan lokasi, keterbatasan sarana prasarana produksi, tidak adanya penetapan harga jual produk budidaya oleh pemerintah daerah, rendahnya kualitas produk budidaya, serta rendahnya aplikasi teknologi hingga belum adanya kelembagaaan yang menaungi pembudidaya merupakan permasalahan yang dihadapi oleh pembudidaya laut di Pulau Dullah. Peneltian ini bertujuan untuk menganalisis tingkat kerentanan di wilayah pesisir Pulau Dullah, Kota Tual melalui pendekatan spasial.

\section{METODE PENELITIAN}

Penelitian dilakukan di Teluk Luv (Pulau Dullah bagian selatan) dan Teluk Divur (Pulau Dullah bagian utara) yang merupakan bagian dari Kecamatan Dullah Utara. 


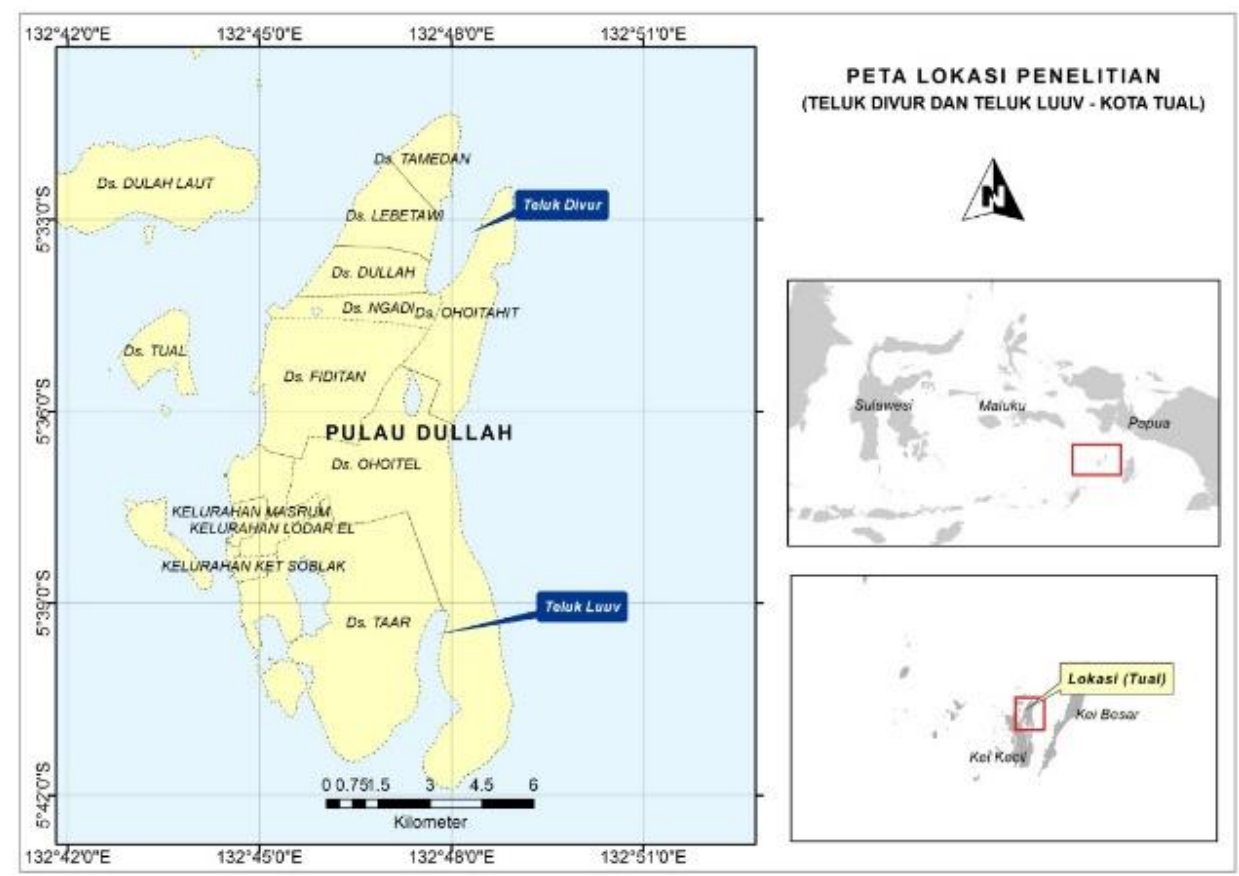

Gambar 1 Lokasi Penelitian

Penentuan kerentanan pesisir teluk dilakukan untuk mengetahui nilai indeks kerentanan pesisir teluk menggunakan modifikasi konsep kerentanan pesisir Gornitz dan White(1992). Metode penelitian kerentanan pesisir teluk menggunakan pendekatan spasial dengan berdasarkan pada kondisi fisik pesisir teluk.

\section{Metode pengumpulan data}

Data yang dikumpulkan meliputi data primer dan data sekunder. Data primer adalah data yang secara langsung didapatkan di lokasi penelitian, baik melalui pengukuran, pengambilan contoh, pengamatan maupun wawancara dengan responden. Adapun data sekunder adalah data yang telah dikumpulkan dan dipublikasikan oleh pihak lain (Tabel 1).

Tabel 1 Teknik pengumpulan data

\begin{tabular}{|c|c|c|c|}
\hline No & Jenis Data & $\begin{array}{c}\text { Teknik Pengumpulan } \\
\text { Data }\end{array}$ & Keterangan \\
\hline 1. & Kenaikan muka laut & $\begin{array}{l}\text {-data rekaman tide gauge } \\
\text {-data dari model SRES } \\
\text {-data AVISO }\end{array}$ & $\begin{array}{l}\text { Penelitian ini } \\
\text { menggunakan data dari } \\
\text { AVISO }\end{array}$ \\
\hline 2. & Tinggi gelombang & Data AVISO & \\
\hline 3. & $\begin{array}{l}\text { Tunggang pasut } \\
\text { maksimal }\end{array}$ & Menggunakan tide gauge & $\begin{array}{l}\text { Diperoleh dari Dinas } \\
\text { Hidrooseanografi }\end{array}$ \\
\hline 4. & $\begin{array}{l}\text { Perubahan garis } \\
\text { pantai }\end{array}$ & $\begin{array}{l}\text { Pengukuran pantai yang } \\
\text { mengalami erosi atau akresi }\end{array}$ & $\begin{array}{l}\text { Diperoleh dari hasil } \\
\text { wawancara dengan } \\
\text { masyarakat terkait } \\
\text { perubahan garis pantai }\end{array}$ \\
\hline
\end{tabular}



5. Elevasi pantai Pengukuran dan pemetaan dengan menggunakan alat total station

6. Geomorfologi pantai Pengamatan lapangan dari tahun sebelumnya

Diamati secara langsung
di lapangan kemudian
diplotkan ke dalam peta
yang diteliti

\section{Metode analisis data}

Pada penelitian ini, analisis data yang dilakukan pada dasarnya menampilkan hubungan antar informasi yang akan dijadikan dasar penelitian. Kriteria dan tolok ukurnya berupa parameter-parameter fisik yang ditentukan berdasarkan modifikasi kajian dari Gornitz (1991) yaitu geomorfologi, perubahan garis pantai, elevasi, kenaikan muka laut relatif, tunggang pasang maksimal dan tinggi gelombang. Dalam artikel tersebut dijelaskan mengenai pengelompokkan indeks kerentanan pesisir teluk ke dalam lima kelompok yaitu sangat tidak rentan, tidak rentan, sedang, rentan, dan sangat rentan. Penilaian secara kuantitatif terhadap kerentanan pesisir dilakukan melalui scoring. Pemberian scoring sesuai dengan kriteria dapat dilihat pada Tabel 2.

Tabel 2 Penilaian skor variabel fisik pesisir teluk

\begin{tabular}{|c|c|c|c|c|c|c|}
\hline \multirow[b]{2}{*}{ No } & \multirow[b]{2}{*}{ Parameter } & \multicolumn{5}{|c|}{ Skor } \\
\hline & & $\begin{array}{c}\text { Sangat } \\
\text { tidak } \\
\text { rentan } \\
1 \\
\end{array}$ & $\begin{array}{c}\text { Tidak } \\
\text { rentan } \\
2 \\
\end{array}$ & $\begin{array}{c}\text { Sedang } \\
3 \\
\end{array}$ & $\begin{array}{c}\text { Rentan } \\
4 \\
\end{array}$ & $\begin{array}{c}\text { Sangat } \\
\text { rentan } \\
5 \\
\end{array}$ \\
\hline $\mathrm{a}$ & geomorfologi & $\begin{array}{l}\text { Batuan } \\
\text { beku }\end{array}$ & $\begin{array}{l}\text { Batu } \\
\text { karang }\end{array}$ & & Lumpur & pasir \\
\hline $\mathrm{b}$ & $\begin{array}{l}\text { Perubahan garis } \\
\text { pantai (m/thn) }\end{array}$ & $>2,0$ & $1,0-2,0$ & $1,0-(-1,0)$ & $-1-(-2)$ & $<-2,0$ \\
\hline $\mathrm{c}$ & Elevasi (m) & $>30,0$ & $20,1-30,0$ & $10,1-20,0$ & $5,1-10,0$ & $0,0-5,0$ \\
\hline d & $\begin{array}{l}\text { Kenaikan muka } \\
\text { laut relatif } \\
(\mathrm{mm} / \mathrm{thn})\end{array}$ & $<-0,1$ & $-1,0-0,99$ & $1,0-2,0$ & $2,1-4,0$ & $>4,0$ \\
\hline e & $\begin{array}{l}\text { Tunggang pasut } \\
\text { maks (m) }\end{array}$ & $<1,0$ & $1,0-1,9$ & $2,0-4,0$ & $4,1-6,0$ & $>6,0$ \\
\hline$f$ & $\begin{array}{l}\text { Tinggi gelombang } \\
\text { (m) }\end{array}$ & $<0,75$ & $0,75-1,0$ & $1,0-1,25$ & $1,25-1,50$ & $>1,50$ \\
\hline
\end{tabular}

Sumber: Gornitz (1991)

Masing-masing parameter yang telah memiliki skor dihitung kerentanannya. Penentuan tingkat kerentanan dilakukan dengan mengadopsi dan memodifikasi dari persamaan umum mengenai indeks kerentanan pesisir (IKP). Dalam penelitian ini, indeks kerentanan pesisir dihitung berdasarkan persamaan yang dikemukakan oleh Gornitz dan White (1992) yaitu sebagai berikut: 


$$
I K P=\sqrt{\frac{(a * b * c * d * e * f)}{6}}
$$

$$
\begin{aligned}
\text { dimana: } a=\text { geomorfologi } & \mathrm{b}=\text { perubahan garis pantai } \\
\mathrm{c}=\text { elevasi } & \mathrm{d}=\text { kenaikan muka laut relatif } \\
\mathrm{e}=\text { tunggang pasut maksimal } & \mathrm{f}=\text { tinggi gelombang }
\end{aligned}
$$

Persamaan IKP menggambarkan seberapa besar tingkat kerentanan terhadap parameter fisik di laut. Nilai IKP yang didapat selanjutnya dikelompokkan tingkat kerentanannya menjadi tiga wilayah yaitu tidak rentan, sedang dan sangat rentan. Pembagian tingkat kerentanan ini sesuai dengan pembagian indeks yang dilakukan oleh Gornitz dan White (1992) yang berdasarkan persen dengan kisaran antar kelas adalah 33 persen.Nilai yang kisarannya kurang dari 33 persen termasuk kedalam indeks tidak rentan dengan warna indikator biruKA. Nilai yang berada pada kisaran 34-66 persen termasuk kedalam indeks sedang dengan warna indikator kuning. Nilai yang kisarannya lebih dari 67 persen termasuk kedalam indeks sangat rentan dengan warna indikator merah.

\section{HASIL DAN PEMBAHASAN}

Peta kerentanan pesisir (indeks kerentanan pesisir/IKP) di Teluk Divur dan Teluk Luv di Pulau Dullah pada dua musim yaitu musim barat, dan musim timur disajikan pada Gambar 2 dan 3.

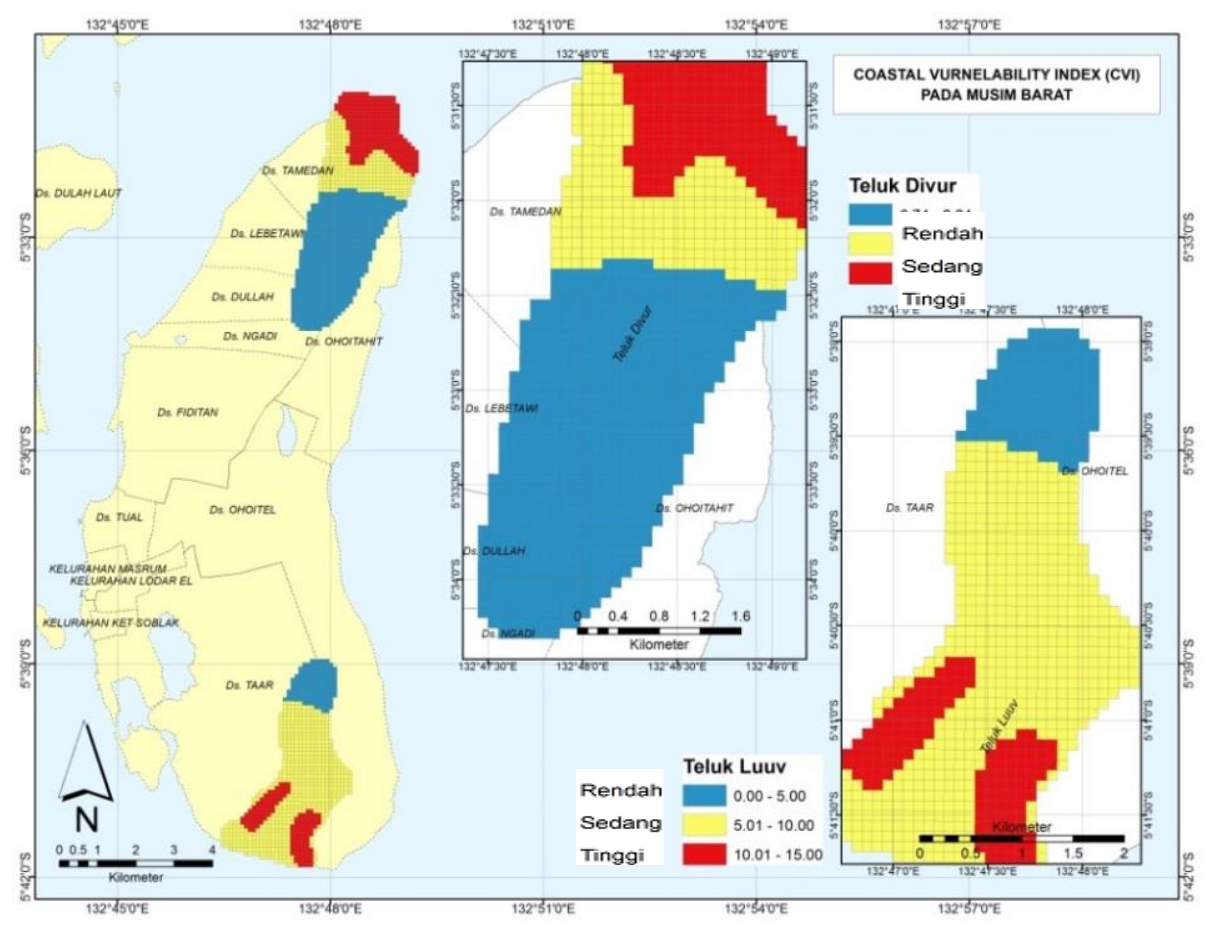

Gambar 2 IKP musim barat 


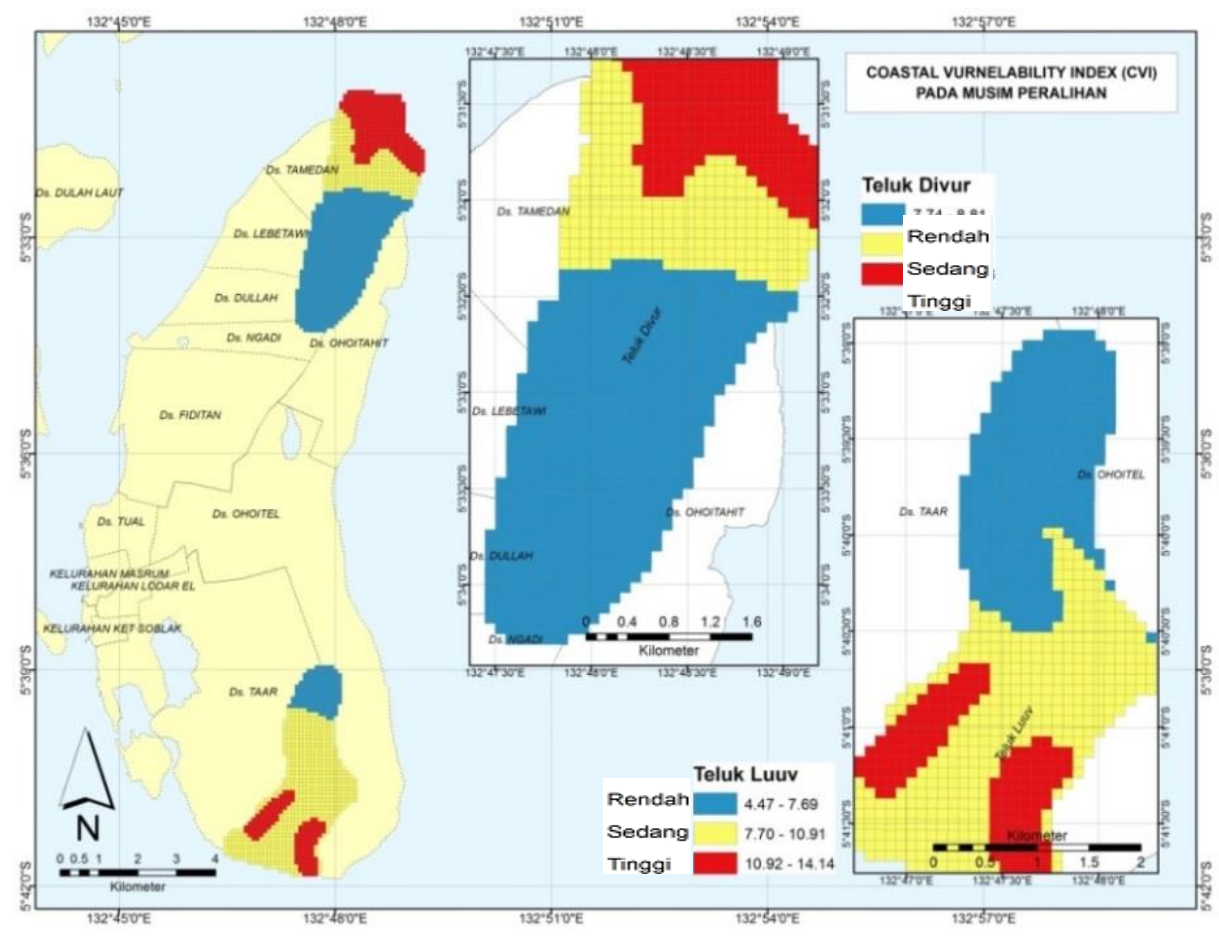

Gambar 3 IKP musim timur

Indeks kerentanan dapat digunakan sebagai indikator tingkat kerentanan. Tingkat kerentanan merupakan suatu hal yang penting untuk diketahui karena dapat berpengaruh terhadap terjadinya bencana. Bencana baru akan terjadi pada kondisi yang rentan. Pembagian kelas atau tingkat kerentanan didasarkan pada penelitian yang dilakukan oleh Gornitz dan White (1992) dimana kelas tersebut dibagi berdasarkan persen dengan jarak antar kelas adalah 33\%. Nilai yang termasuk dalam persen kurang dari sama dengan 33 termasuk kedalam indeks tidak rentan. Nilai yang termasuk dalam persen antara 34 sampai 67 termasuk indeks sedang sedangkan nilai yang termasuk dalam persen lebih dari 67 termasuk indeks rentan.

Pada musim barat, nilai indeks kerentanan pesisir di Teluk Divur berkisar antara 6,74-11,62 sedangkan di Teluk Luv berkisar antara 0,00-15.00. Pada musim peralihan, nilai indeks kerentanan pesisir di Teluk Divur berkisar antara 7,74-10,96 sedangkan di Teluk Luv berkisar antara 4,47-14,14. Pada musim timur, diperoleh nilai indeks kerentanan pesisir berkisar 11,61-15,00 di Teluk Divur dan 7,74 - 19,37 di Teluk Luv. Tingkat kerentanan pesisir Teluk Divur di tiga musim tidak berbeda jauh berkisar antara 6,74-15,00.

Pada Teluk Luv, tingkat kerentanan pesisir pada musim peralihan dan musim timur sedikit berbeda dengan musim barat. Teluk Divur di setiap musim memiliki wilayah perairan yang rentan pada posisi di depan teluk sedangkan pada Teluk Luv pada kiri dan kanan mulut teluk. Hal ini diduga karena di mulut teluk, pengaruh pasang surut di perairan laut lepas masih tinggi yang mempengaruhi arus pada bagian mulut teluk (Rampengan 2009). Selain itu, Pola pergerakan arus yang dihubungkan dengan proses pasang surut merupakan gaya penggerak utama sirkulasi massa air di perairan sempit dan semi tertutup seperti teluk (Rampengan 2009; Hadikusumah 2008) dan 
menyangkut massa air dalam jumlah sangat besar dan memiliki arah yang bolak balik (Triatmodjo 1999). Untuk perairan teluk, pengaruh pasang surut lebih dominan dari pengaruh musim dan gelombang (CRMP 1998). Selain itu, pasang surut juga menyebabkan arus yang terjadi di perairan teluk dan laguna yang diakibatkan oleh massa air yang mengalir dari permukaan yang lebih tinggi ke pemukaan yang lebih rendah. Pada waktu gelombang pasang surut merambat memasuki perairan dangkal seperti muara sungai atau teluk maka badan air kawasan ini akan bereaksi terhadap aksi dari perairan lepas (Wirasatriya et al. 2006).

Pasang surut adalah fluktuasi (gerakan naik turunnya) muka air laut secara berirama karena adanya gaya tarik benda-benda di langit, terutama bulan dan matahari terhadap massa ar laut di bumi. Pasangan matahari dan bumi menghasilkan fenomena pasang surut yang mirip dengan fenomena yang diakibatkan oleh pasangan bumi bulan tergantung dari gaya penggerak pasut (GPP). GPP yang disebabkan matahari hanya separuh kekuatan yang disebabkan bulan. Hal ini disebabkan oleh jarak bulan ke bumi yang lebih dekat dari jarak matahari ke bumi. Sifat pasang surut yang periodik meyebabkan data pasang surut dapat diramalkan (Mahatmawati et al. 2009). Oleh karena itu semakin kedalam teluk, tingkat kerentanan perairan semakin rendah karena kecepatan arus relatif lemah dan terhalangnya energi yang besar serta keterbatasan hidrodinamika air (Wisha et al. 2015).

\section{KESIMPULAN}

Teluk Divur dan Teluk Luv memiliki perairan yang masuk kedalam kategori tidak rentan hingga rentan sedang dengan nilai indeks kerentanan berkisar 0,00-19,37 untuk dua musim (musim barat, dan musim timur). Posisi mulut teluk memiliki tingkat kerentanan yang lebih tinggi dari teluk bagian dalam.

\section{DAFTAR PUSTAKA}

[BPS Maluku Tenggara] Badan Pusat Statistik Maluku Tenggara. (2015). Statistik Daerah Kota Tual.

Constanza RJ, Cumbeland, Maxell T. (1997). AnIntroduction to Ecological Economics. St.lucie, Boca Raton. Florida.

CRMP. (1998). Kondisi oseanografi perairan pesisir Lampung. Proyek Pesisir Publication, Technical Report (TE-99/12-I) Coastal Resources Center, University of Rhode Island. Jakarta, Indonesia.

Dinas Kelautan dan Perikanan Kota Tual. (2010). Master plan minapolitan Kota Tual. Tual. Maluku.

FAO. (2016). The state of world fisheries and aquaculture 2016. Contributing to food security and nutrition for all. Rome.

Gornitz, V.(1991). Vulnerability of the East Coast, U.S.A. to future sea level rise. Journal of Coastal Research, Special Issue No. 9, p. 201-237.

Gornitz, V. and White, T. W. (1992). A coastal hazards database for the U.S. East Coast. ORNL/CDIAC-45, NDP-043A. Oak Ridge National Laboratory, Oak Ridge, Tennessee. 
Hadikusumah. (2008). Variabilitas suhu dan salinitas di perairan Cisadane. Makara Sains 12(2):82-88.

Mahatmawati, A.D, Mahfud, E, Aries D.S. (2009). Perbandingan fluktuasi muka air laut rerata (MLR) di perairan Pantai Utara Jawa Timur dengan perairan pantai selatan Jawa Timur. Jurnal Kelautan 2(1):31-39.

[Pusdatin KKP] Pusat Data, Statistik dan Informasi Kementerian Kelautan dan Perikanan. (2016). Statistik Kelautan dan Perikanan 2015. Jakarta.

Rampengan RM. (2009). Pengaruh pasang surut pada pergerakan arus permukaan di Teluk Manado. Jurnal Perikanan dan Kelautan V(3):15-19.

Tompkins EL, Ncholso-Cole SSA., Hurlston L, Boyd E, Hodge GB, Clarke J, Gray G, Trotz N, Varlack L.(2005). Surviving climate change in small islands- a guide book. Tyndall Center for Climate Change Research, UK.

Triatmodjo B. (1999). Teknik pantai. Universitas Gadjah Mada. Yogyakarta. 99-101.

Wisha UJ, Husrin S, Prihantono J. (2015). Hidrodinamika perairan Teluk Banten pada musim peralihan (Agustus-September). Ilmu Kelautan 20(2):101-112. 